\title{
RUMAH KACA PINGGIR KOTA DI DAAN MOGOT
}

\author{
Valdo Helmy ${ }^{1)}$, Sutarki Sutisna ${ }^{21}$ \\ 1) Program Studi S1 Arsitektur, Fakultas Teknik, Universitas Tarumanagara, helmy_valdo@yahoo.com \\ 2) Program Studi S1 Arsitektur, Fakultas Teknik, Universitas Tarumanagara, sutarkis@gmail.com
}

\begin{abstract}
Abstrak
DKI Jakarta sebagai ibukota negara terdiri dari 5 wilayah dan 1 kabupaten. Jakarta memiliki kepadatan penduduk tertinggi di Indonesia. Di masa modern ini penduduk cenderung tinggal dan beraktivitas di daerah perkotaan dengan demikian muncul permasalahan psikologis berupa stres. Dalam kehidupan perkotaan, stres tersebut diakibatkan karena aktivitas rutinitas sehari-hari dimana semua orang beraktivitas di antara kedua tempat yaitu tempat tinggal dan tempat kerja. Rutinitas ini dapat menimbulkan permasalahan yang dimulai dari perasaan bosan dan jenuh hingga bisa mengakibatkan suatu penyakit mental yang awalnya berupa stres, gangguan kecemasan, dan psikosis yang bisa menjadi depresi. Langkah yang dapat dilakukan adalah untuk membuat suatu tempat ketiga di luar dari kehidupan rumah tangga di tempat tinggal dan di luar kehidupan profesional di tempat kerja yang bertujuan untuk mengurangi gejala-gejala psikologis yang mengakibatkan stres. Selain dari itu dikatakan bahwa interaksi secara langsung dengan alam dapat membantu seorang manusia untuk memperkuat daya tahan mental mereka untuk menghadapi tekanan-tekanan yang mengakibatkan stres. Rancangan yang diajukan sebagai solusi berupa sebuah ruang publik terbuka berupa plaza diantara dua bangunan berupa bangunan komersil dan bangunan rumah kaca dimana bangunan komersil berupa pujasera, pasar modern, café, toko buku, ruang baca, serta workshop, sementara rumah kaca berfungsi untuk memproduksi hasil berupa hasil kebun kepada fungsi komersil dan sebagai fungsi rekreasi. Selain dari fungsi di dalam bangunan dalam upaya mendorong minat pengunjung tapak terhadap kegiatan berkebun serta memberikan interaksi langsung dengan alam, dibuat sebuah fungsi kebun komunitas dimana perngunjung yang mendatangi tapak dapat menanam tanaman yang mereka inginkan pada area yang disediakan di tapak.
\end{abstract}

Kata kunci: hijau; jakarta; ruang publik; rutinitas; stres

\begin{abstract}
DKI Jakarta as the capitol consists of 5 regions and 1 district. Jakarta has the highest population density in Indonesia. In this modern ag, the population tends to live and work in the city thus psychological problems arise in the form of stress. In the urban lifestyle, stress is caused due to daily routine where everybody is active between two places namely residence and work place. This routine can cause problems that begins with the feeling of boredom which can lead to a mental illness that is initially in the form of stress, anxiety disorder, and psychosis which can be worsen into depression. The step that can be made is to make a third place outside of domestic life at home and outside of professional life at work that aims to reduce psychologial symptoms that causes stress. Apart from that, it is said that a direct interaction with nature can help humans to strengthen their mental endurance to deal with symptoms that causes stress. The proposed design as a solution is in the form of an open public space, a plaza between two buildings, commercial building and a greenhouse where the commercial building has several functions such as food court, market, café, book shops, reading area, and workshop. While the greenhouse gives garden products to support the commercial functions and as a recreational spot. Apart from the functions within the buildings, in effort to encourage visitors into gardening activities and provide direct interactions to nature, community garden serves as a solution in which visitors can plant crops or plants if they wanted to in the provided area on the site.
\end{abstract}

Keywords: green; jakarta; public space; routine; stress 


\section{PENDAHULUAN}

Pada zaman yang sudah serba cepat ini seiring dengan berjalannya waktu, ilmu dan teknologi sudah berkembang sangat pesat sehingga memicu persaingan ketat di kehidupan profesional dan pendidikan manusia. Tuntutan dalam dunia pekerjaan dan pendidikan ini memberikan tekanan pada semua orang untuk memberikan hasil yang lebih dari yang sebelumnya. Selain dari kehidupan profesional dalam tempat kerja dan pendidikan dalam sekolah maupun kampus, ada pula kehidupan berumah tangga di tempat tinggal manusia. Di dalam kehidupan berumah tangga pun terdapat tekanan dimana seseorang dituntut untuk berperan menjadi seorang anggota keluarga baik menjadi ayah, ibu, maupun anak.
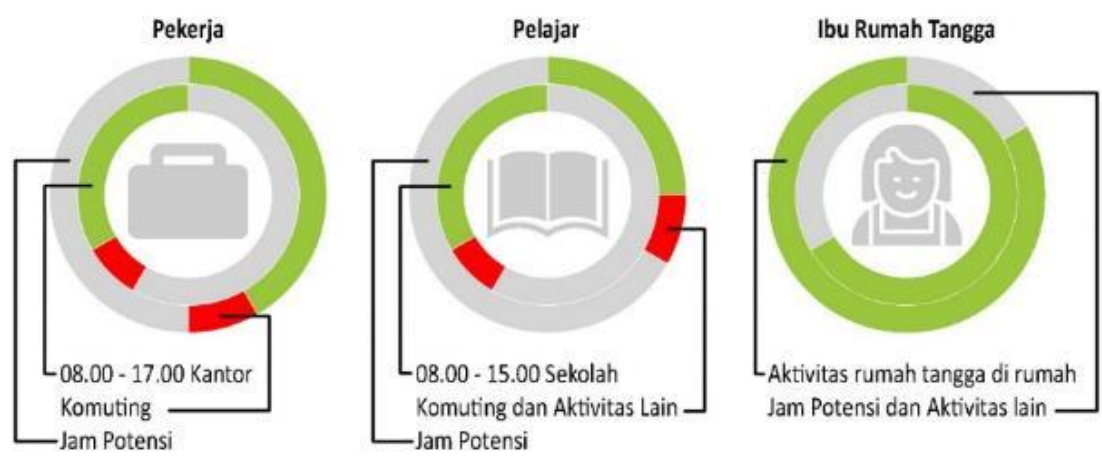

Gambar 1. Diagram Waktu Rutinitas sehari-hari Sumber: Penulis, 2019

Menurut survei yang dilakukan oleh Perhimpunan Dokter Spesialis Kedokteran Jiwa Indonesia (PDSKJII) dr. Eka Viora, SpKJ menunjukkan bahwa di Indonesia terdapat sekitar 15.6 juta penduduk yang mengalami depresi, dan yang disayangkannya hanya $8 \%$ yang berusaha untuk mencari pengobatan ke tangan profesional. Hal ini dikarenakan karena pandangan masyarakat terhadap depresi sebagai penyakit psikologis yang dianggap sebagai suatu perihal yang aib (Azizah, 2019). Dibandingkan dengan penyakit secara fisik tanpa mengetahui hal yang lebih umum bahwa tekanan hidup yang berlebihan yang dapat mengakibatkan stres dan berujung menjadi depresi ini dapat mempengaruhi semua orang dan bukan yang seharusnya menjadi suatu perihal yang aib. Permasalahan yang dialami dari gaya hidup yang banyak tekanan baik di tempat tinggal maupun tempat bekerja ini memunculkan adanya kebutuhan suatu tempat lain diluar dari tempat tinggal maupun tempat bekerja yang bebas dari tekanan kehidupan sehari-hari dimana seseorang dapat mendatangi tempat tersebut secara bebas kapanpun mereka mau.

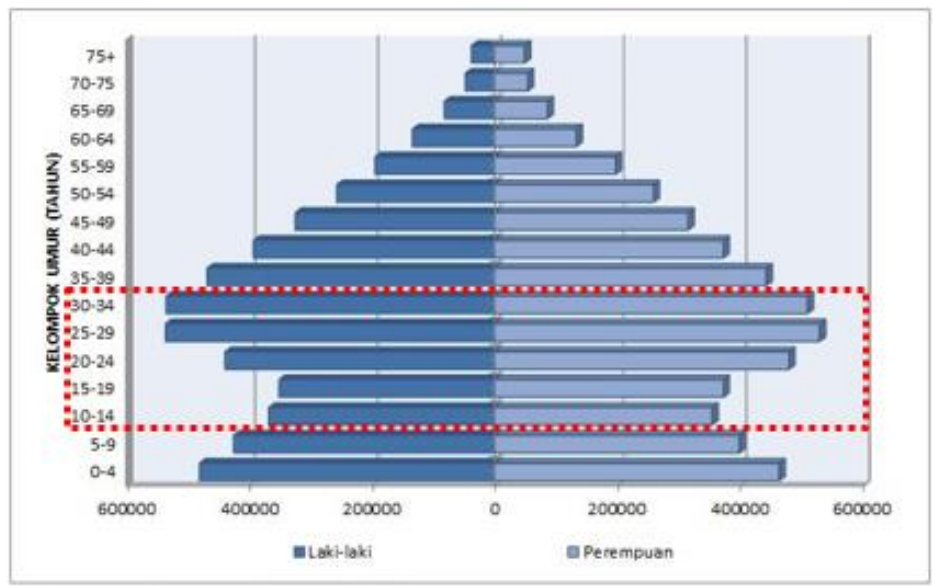

Gambar 2. Piramida Penduduk di Jakarta Sumber: BPS Provinsi DKI Jakarta 2015 
Menurut Collin Ellard PhD., taman kota dibutuhkan tidak hanya untuk estetika yang baik atau sebagai ruang publik yang ceria saja, tetapi juga karena telah terbukti bahwa taman tersebut dapat menyembuhkan pikiran dan tubuh (Ellard, 2012). Sementara dalam perwujudan kota yang baik, jumlah Ruang Terbuka Hijau (RTH) dia Jakarta baru tercapai 9.98\% dari total 30\% target ideal yang diharapkan (Jakarta Smart City, 2017). Dalam mewujudkan solusi yang diinginkan perlu dipertimbangkan lokasi yang efektif untuk pembangunan ruang publik tersebut terkait dengan Transit Oriented Development (TOD) dimana para komuter dan para pejalan kaki yang diutamakan dalam percangannya. Serta pembangunan yang berkontribusi dalam tercapainya Sustainable Development Goals (SDG).

Jakarta Barat merupakan bagian dari kota Jakarta yang terletak di tengah-tengah jantung ibukota Jakarta karena merupakan pusat pemerintahan, bisnis, perekonomian, politik, dan pendidikan. Selain dari itu di kawasan seperti Cengkareng dan Kalideres terdapat banyak hunian perumahan dan sarana pendidikan berupa sekolah. Dan untuk lokasi tapak terpilih berada di kawasan Kalideres tepatnya di Jl. Kintamani Raya dekat dengan Jl. Daan Mogot Raya. Di sepanjang Jl. Daan Mogot Raya terdapat banyak kawasan industri, dari letak kawasannya yang didominasi dengan hunian komplek, perkampungan, sekolah, industri, dan perkantoran menjadikan demografi kawasan ini sangat beragam. Sebagian besar dari yang tinggal di kawasan tersebut dalam rutinitas sehari-harinya bepergian untuk bekerja di pusat kota, ada juga yang tinggal dan bekerja di sekitar kawasan, dan ada juga sebagian yang mendatangi kawasan tersebut untuk bekerja.

Lokasi kawasan terpilih karena Kalideres memiliki demografi penduduk dan pengunjung kawasan yang sangat beragam. Selain dari itu, lokasi tapak dinilai strategis karena memiliki hubungan erat dengan kegiatan rutinitas sehari-hari serta akses yang mudah dengan moda transportasi umum berbasis TOD, dalam hal lokasi tapak ini dilayani dengan Halte Busway Pesakih yang berjarak $\pm 150 \mathrm{~m}$ dari tapak. Dalam kaitannya dengan teori The Third Place sebagai panduan membangun sebuah ruang publik yang ideal, lokasi tapak yang memiliki akses yang mudah dicapai terutama dengan moda transportasi umum dan pejalan kaki menjadi sangat penting. Diluar dari kriteria pemilihan tapak, dalam segi perancangan proyek ini, program yang dibentuk diharapkan dapat membantu dalam meringankan atau menyelesaikan permasalahan yang dikemukakan berupa stres.

\section{KAJIAN LITERATUR}

\section{Tinjauan Stres dan Kehidupan Perkotaan}

Stres adalah bagaimana cara otak dan tubuh merespon terhadap setiap permintaan. eperti olahraga, pekerjaan, sekolah, perubahan besar dalam hidup, atau peristiwa traumatis - dapat memicu stress ( 5 things you should know about stress, n.d.) Studi membuktikan bahwa penghuni kota yang lahir dan besar di lingkungan perkotaan memiliki tingkat psikosis, gangguan kecemasan, dan depresi yang lebih tinggi. Dan efek itu mungkin tidak tergantung pada faktorfaktor pendukung seperti sejarah keluarga ataupuan status sosial ekonomi (Ellard, 2012).

\section{Kepadatan}

Kepadatan merupakan jumlah variabel yang meliputi orang, penduduk, pohon, atau luas bangunan dalam suatu wilayah tertentu. Kepadatan dapat bervariasi, tergantung luas area yang digunakan dalam perhitungan. Misalnya, kepadatan dalam suatu area pemukiman pasti lebih tinggi dibandingkan kepadatan dari keseluruhan lingkungan tersebut, karena di dalam lingkungan ada pula lahan yang tidak berfungsi sebagai hunian (Forsyth, 2003). 


\section{Pembangunan Hijau}

Green Infrastructure juga dikenal dengan nama natural infrastructure atau nature-based solutions, menggambarkan struktur blok bangunan dari komunitas mulai dari dalam skala lanskap regional hingga satu situs, alam yang dirancang atau dilestarikan terintegrasi dengan sistem yang dibangun untuk meniru ekologi dan fungsi alam. Solusi berbasis alam sering dimaksudkan untuk mencapai fungsi spesifik seperti membersihkan air, membatasi perubahan iklim, atau juga mengurangi kebisingan lalu lintas. Tetapi mereka juga memberikan berbagai macam manfaat tambahan seperti kesehatan dan kesejahteraan manusia (Wolf, 2016).

\section{Ruang Terbuka Hijau}

Tujuan penyelenggaraan RTH adalah (Direktorat Jenderal Penataan Ruang, 2008):

a. Menjaga ketersediaan lahan sebagai resapan air

b. Menciptakan aspek planologis perkotaan melalui keseimbangan antara lingkungan alam dan lingkungan binaan yang berguna untuk kepentingan masyarakat

c. Meningkatkan keserasian lingkungan perkotaan sebagai sarana pengaman lingkungan perkotaan yang aman, nyaman, segar, indah, dan bersih.

\section{The Third Place}

Sosiologis Ray Oldenburg menyebut "first place" sebagai rumah dan tinggal bersamanya. "Second place" tempat dimana seseorang menghabiskan mayoritas dari waktunya. "Third place" adalah sebuah "anchor" dari kehidupan sebuah komunitas yang memfasilitasikan dan membersarkan interaksi kreatif secara lebih luas. Dalam kata lain, "your third place is where you relax in public, where you encounter familiar faces and make new acquaintances." Third Place adalah "your hangout spot" tempat dimana secara pribadi kita berkumpul yang menyediakan zona penting diluar tempat tinggal dan tempat kerja (Dzubak, n.d.)

\section{Sustainable Development Goals (SDG)}

Sustainable Development Goals atau yang dikenal dengan Global Goals diadopsi bagi seluruh anggota PBB pada tahun 2015 sebagai panggilan global untuk mengakhiri kemiskinan, menjaga bumi, dan memastikan semua orang menikmati perdamaian dan kemakmuran pada tahun 2030 (Sustainable Development Goals, 2015)

\section{METODE}

Metode yang digunakan dalam perancangan proyek ini diawali dengan kajian literatur, menetapkan rumusan masalah, menentukan pemecahan dari masalah yang ditemukan, menganalisis perkotaan untuk menentukan lokasi tapak, menganalisis tapak dan sekitar tapak untuk menentukan potensi yang dimiliki tapak, analisis dan sintesis, menentukan program yang cocok untuk tapak dengan sekitarnya terkait dengan permasalahan dan potensi tapak, menyusun konsep perancangan tapak seperti konsep sirkulasi, zoning, dan gubahan massa.

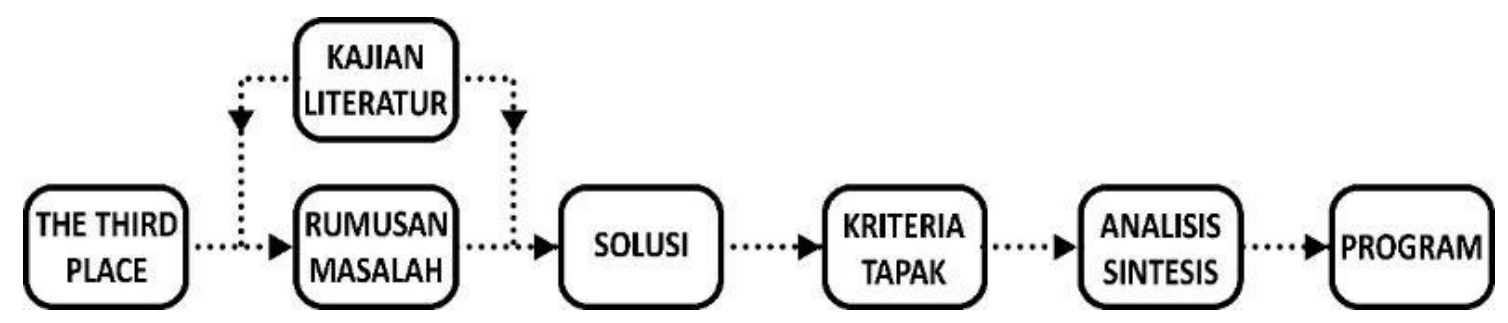

Gambar 3. Skema Metode Perancangan Sumber: Penulis, 2019 


\section{DISKUSI DAN HASIL}

\section{Kawasan}

Lokasi tapak berada di Jl. Kintamani Raya, Kalideres, Jakarta Barat karena lokasi tapak dinilai secara efektif memenuhi kriteria tapak yang dicari untuk proses perancangan:

a. Lokasi di kota Jakarta karena merupakan ibukota serta kota metropolitan dengan tingkat urbanisasi yang tinggi.

b. Jakarta Barat khususnya kawasan Kalideres yang memiliki demografi penduduk dan pengunjung kawasan yang beragam berupa hunian, perkampungan, sekolah, industri, dan perkantoran.

c. Kawasan ditunjang dengan kelengkapan infrastuktur perkotaan

d. Tapak yang strategis dengan akses yang mudah dicapai dengan transportasi umum menjunjung Transit Oriented Development (TOD) berupa bus transjakarta, KRL, rencana MRT dan LRT, dan sebagainya.

e. Tapak memiliki hubungan erat dengan alur kegiatan rutinitas sehari-hari diantara tempat bekerja dan tempat tinggal, sebuah Third Place yang ideal memiliki akses yang sangat mudah, secara makro, akses yang baik berada diantara pergerakan antara First Place dan Second Place, serta dekat dengan area transit TOD.

f. Tapak terintegrasi dengan kegiatan lingkungan sekitar.

g. Pemilihan tapak sesuai dengan perencanaan Tata Ruang Kota
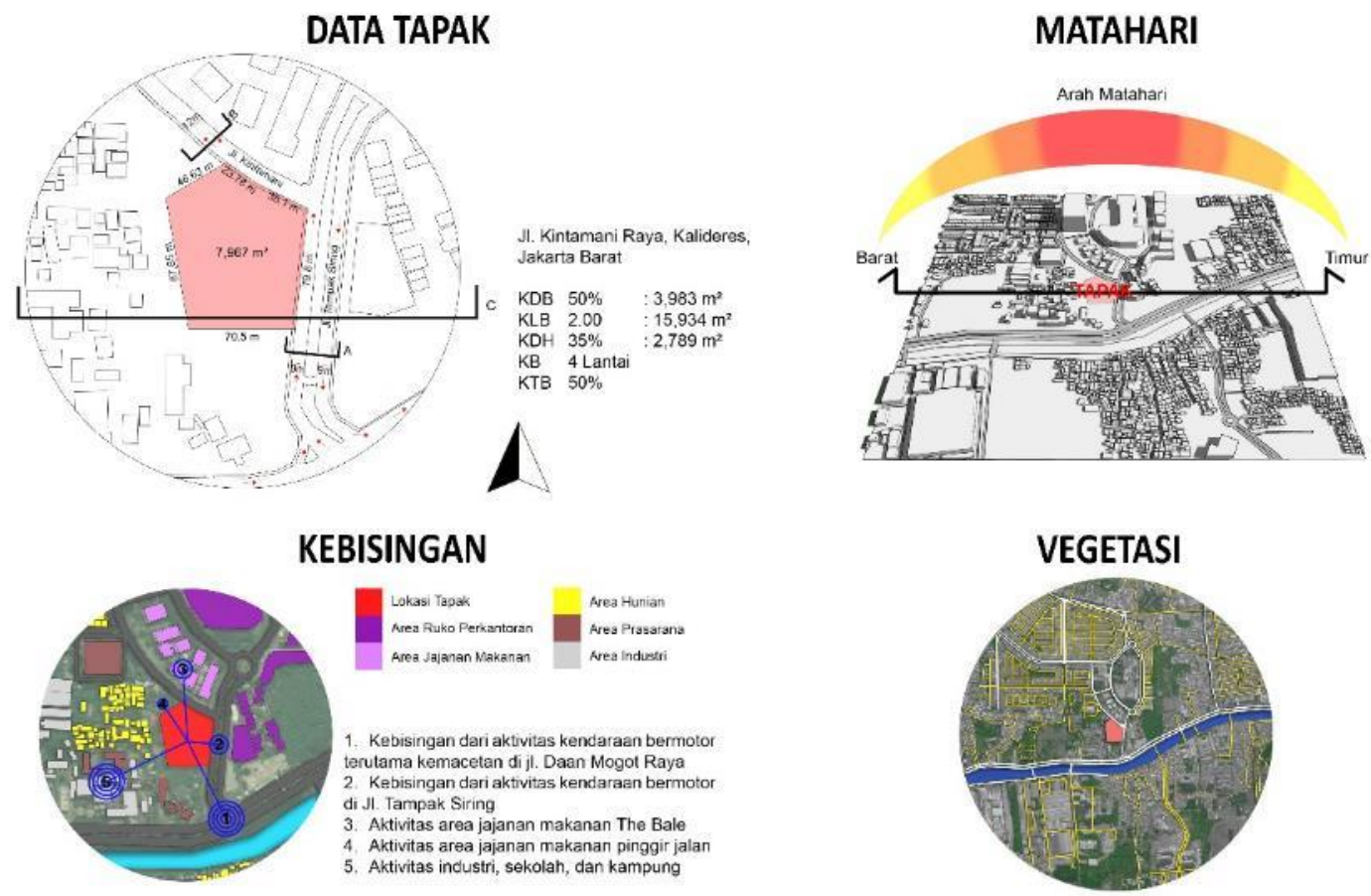

Gambar 4. Data Tapak dan Analisis Sumber: Penulis, 2019

Kebisingan tidak memiliki dampak besar terhadap tapak dikarenakan oleh jarak yang jauh antara sumber kebisingan terbesar dari persimpangan Jl. Daan Mogot Raya, aktivitas industri yang jauh dari tapak, serta kecilnya intensitas kebisingan aktivitas di muka tapak dan di sekitar tapak. Vegetasi yang terlihat dari peta radius $1 \mathrm{~km}$ berupa tanah-tanah kosong yang belum terbangun serta vegetasi yang berada di sepanjang jalan ataupun sebagai pemisah jalan di beberapa badan jalan. Selain dari itu tidak terlihat adanya vegetasi yang bersifat publik maupun Ruang Terbuka Hijau (RTH) dalam radius 1 km. 


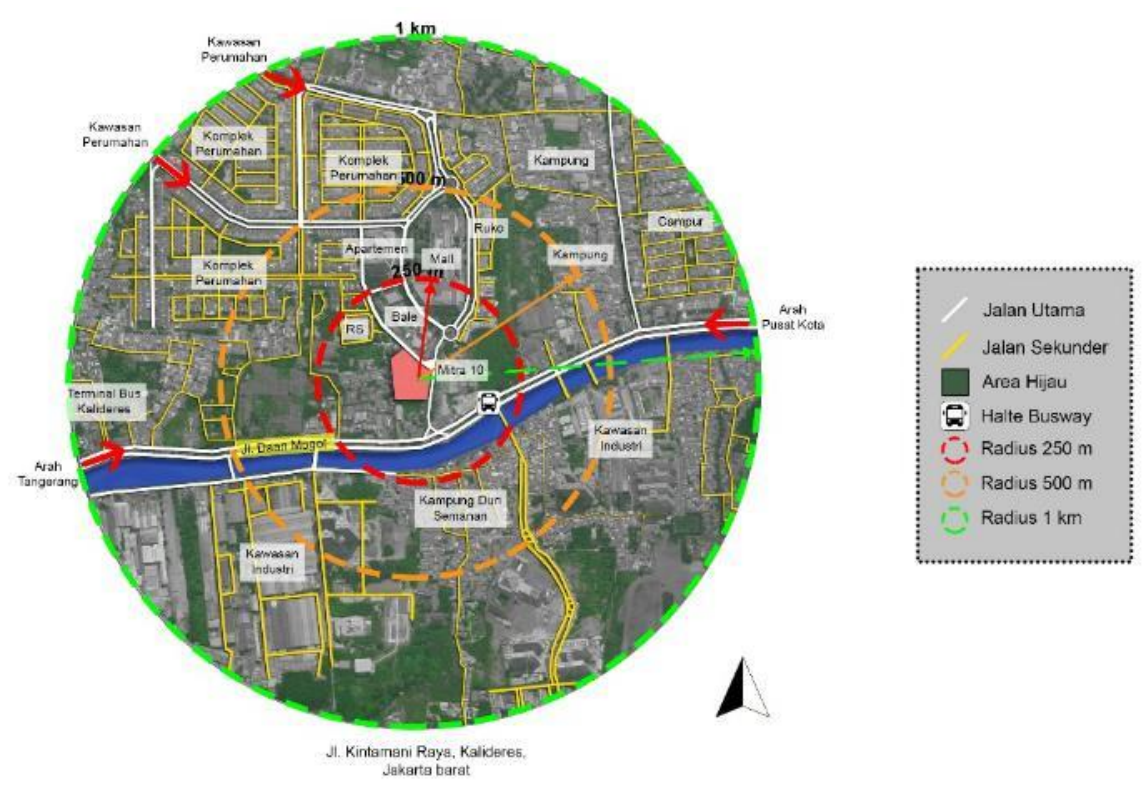

Gambar 5. Fasilitas Sekitar Tapak Radius $1 \mathrm{~km}$ Sumber: Penulis, 2019

Lokasi tapak berada di pinggir kawasan perumahan dengan fungsi di sekitar tapak mayoritas berupa fungsi perkantoran dengan ketinggian 3-4 lantai berupa ruko-ruko, dilengkapi dengan adanya Mall Daan Mogot, Rumah Sakit Hermina, pusat jajanan makanan pinggir jalan, pusat jajanan The Bale, serta Toko Perkakas Mitra 10.

Lokasi Tapak terpilih karena dari segi lokasi yang terpenting adalah kemudahan aksesibilitas bagi semua orang. Dalam kaitannya dengah terbentuknya sebuah Third Place, lokasi terbaik berada di pergerakan antara tempat tinggal dan tempat beokerja dengan mempertimbangkan lokasi halte kendaraan umum yang digunakan komuter untuk pergi dan pulang bekerja setiap harinya seperti KRL, LRT, MRT, atau dalam konteks lokasi tapak ini berupa Halte Busway Pesakih.

Tapak yang berada pada kawasan pemukiman bertujuan sebagai tempat singgah bagi seseorang yang pulang kerja tetapi belum ingin pulang ke rumah. lokasi berada lebih mendekati dengan kawasan pemukiman dengan salah satu bahan pertimbangan berupa jam operasional moda transportasi umum yang pada umumnya berhenti beroperasi pada pukul 22.00 .
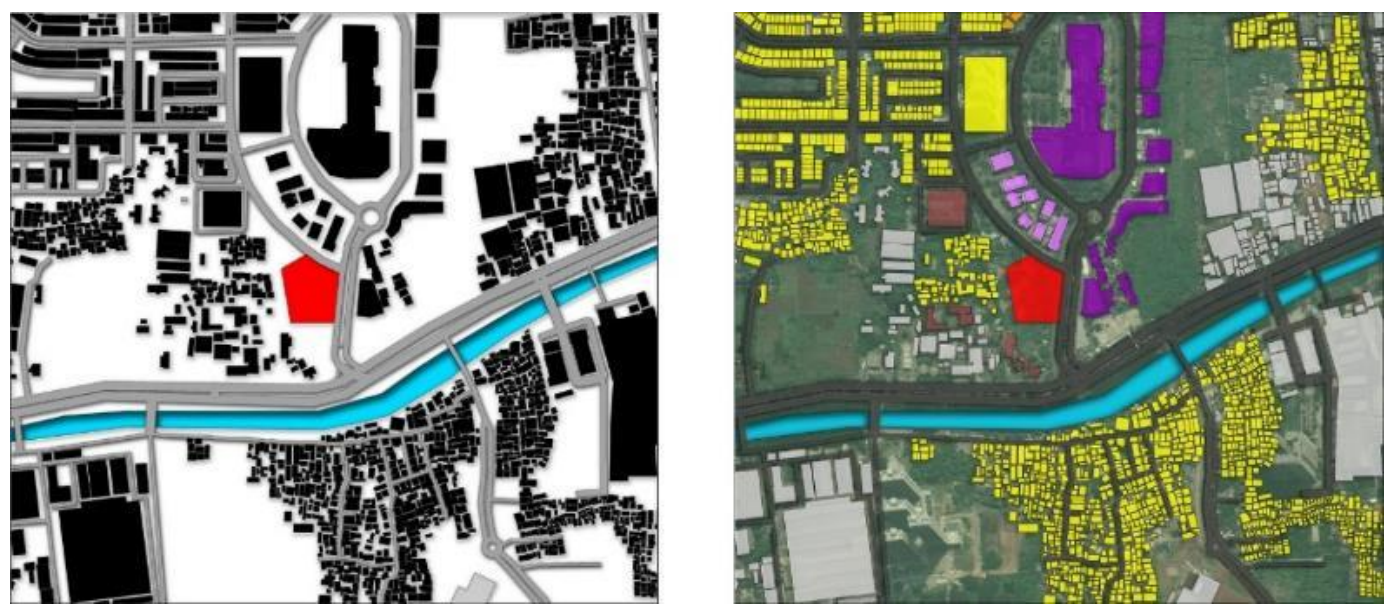

Gambar 6. Noly Map dan Penggunaan Lahan

Sumber: Penulis, 2019 

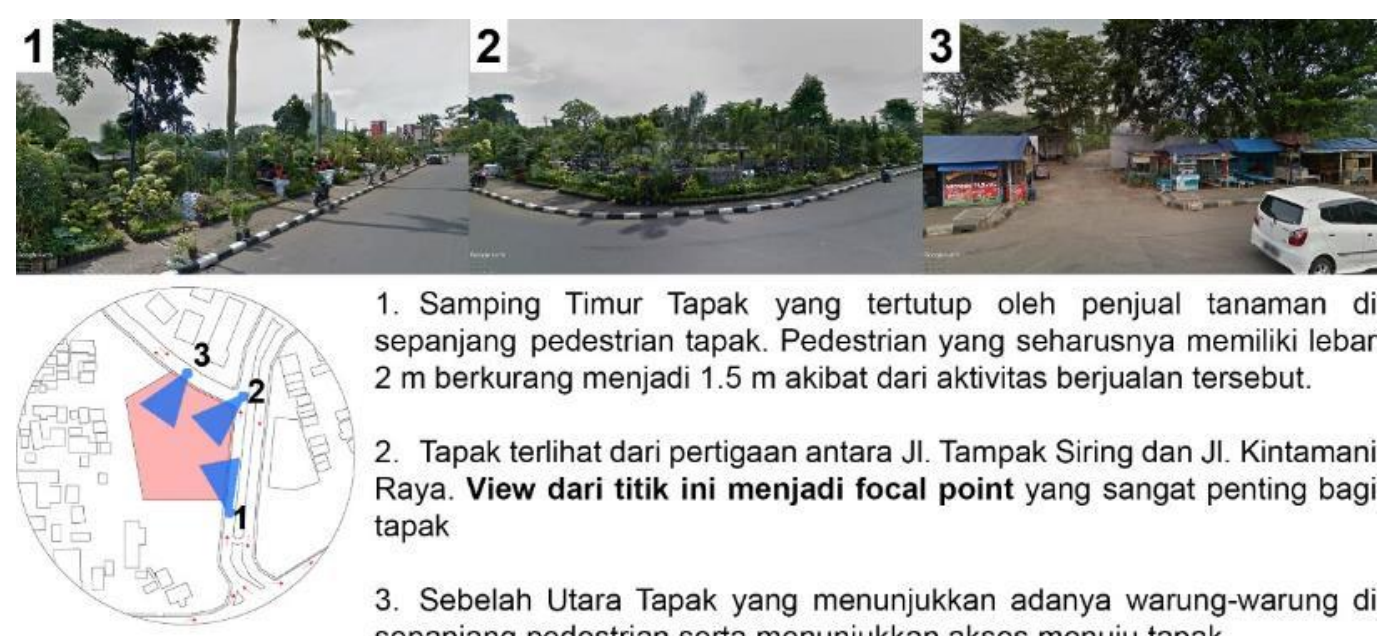

1. Samping Timur Tapak yang tertutup oleh penjual tanaman di sepanjang pedestrian tapak. Pedestrian yang seharusnya memiliki lebar $2 \mathrm{~m}$ berkurang menjadi $1.5 \mathrm{~m}$ akibat dari aktivitas berjualan tersebut.

2. Tapak terlihat dari pertigaan antara JI. Tampak Siring dan JI. Kintamani Raya. View dari titik ini menjadi focal point yang sangat penting bagi tapak

3. Sebelah Utara Tapak yang menunjukkan adanya warung-warung di sepanjang pedestrian serta menunjukkan akses menuju tapak

Gambar 7. View Menuju Tapak

Sumber: Penulis, 2019
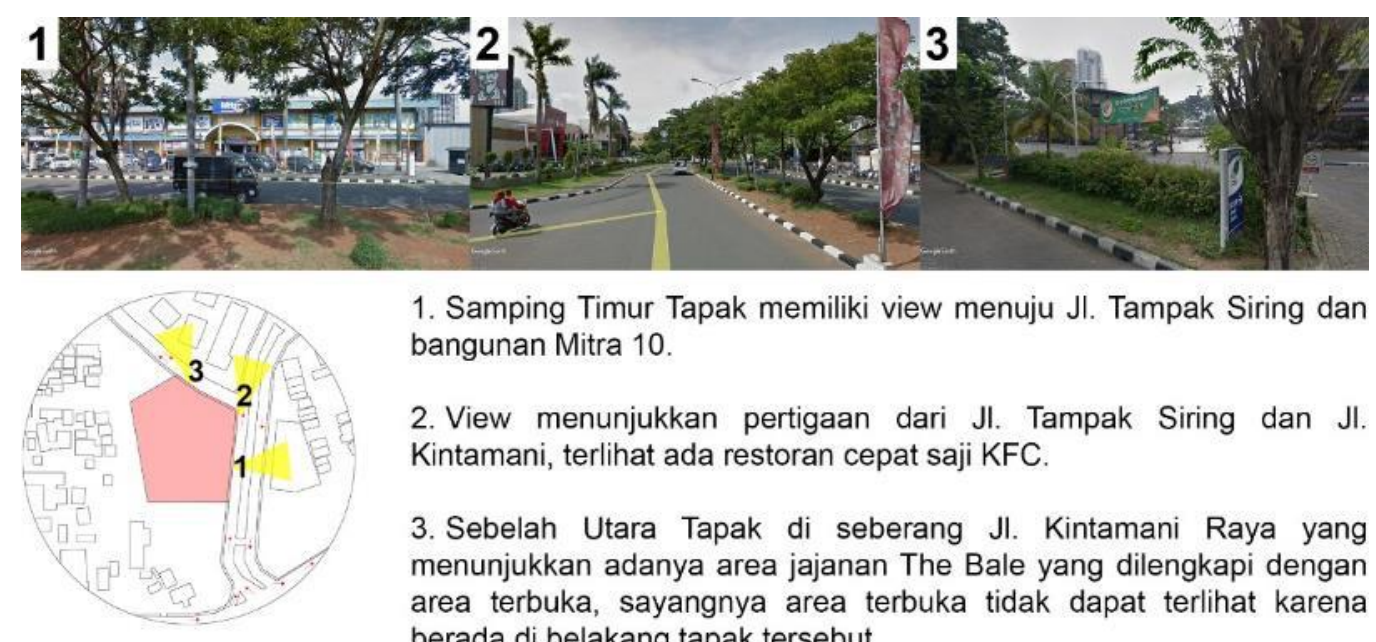

1. Samping Timur Tapak memiliki view menuju Jl. Tampak Siring dan bangunan Mitra 10.

2. View menunjukkan pertigaan dari Jl. Tampak Siring dan Jl. Kintamani, terlihat ada restoran cepat saji KFC.

3. Sebelah Utara Tapak di seberang Jl. Kintamani Raya yang menunjukkan adanya area jajanan The Bale yang dilengkapi dengan area terbuka, sayangnya area terbuka tidak dapat terlihat karena berada di belakang tapak tersebut.

Gambar 8. View Dari Tapak

Sumber: Penulis, 2019

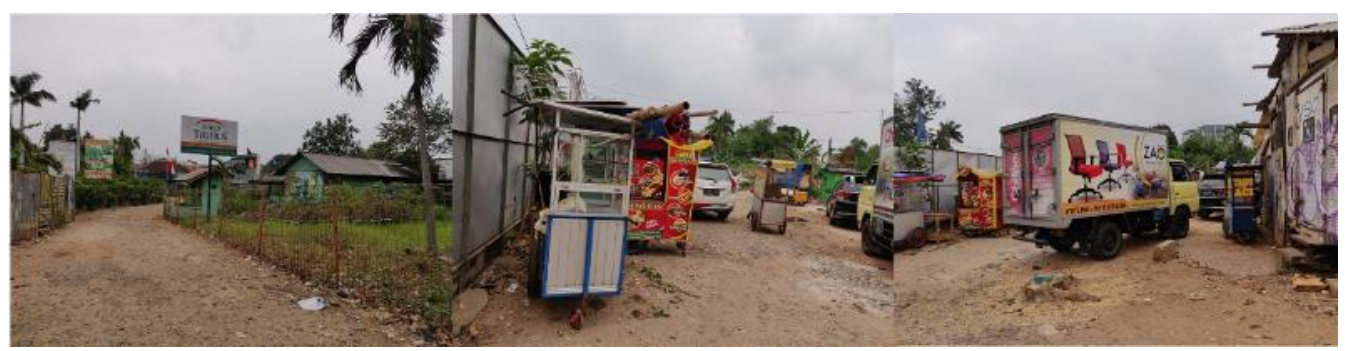

Gambar 9. Eksisting tapak

Sumber: Penulis, 2019

Eksisting tapak berupa toko yang menjual alat-alat dan bahan untuk kebutuhan berkebun berupa Toko Trubus. Tapak ini sendiri masih beroperasi tetapi tidak beroperasi secara efektif, dari keseluruhan tapak yang dimiliki, hanya terdapat 1 bangunan saja yang masih digunakan untuk operasional toko. Sebagian besar dari tapak sudah terlihat gersang dan tidak terawat. Terlihat ada bangunan yang tidak terpakai dan tidak terawat, banyaknya puing-puing sisa gerobak dan area yang menjadi tempat parkir mobil box serta tempat membuang sampah. 


\section{Konsep Perancangan}

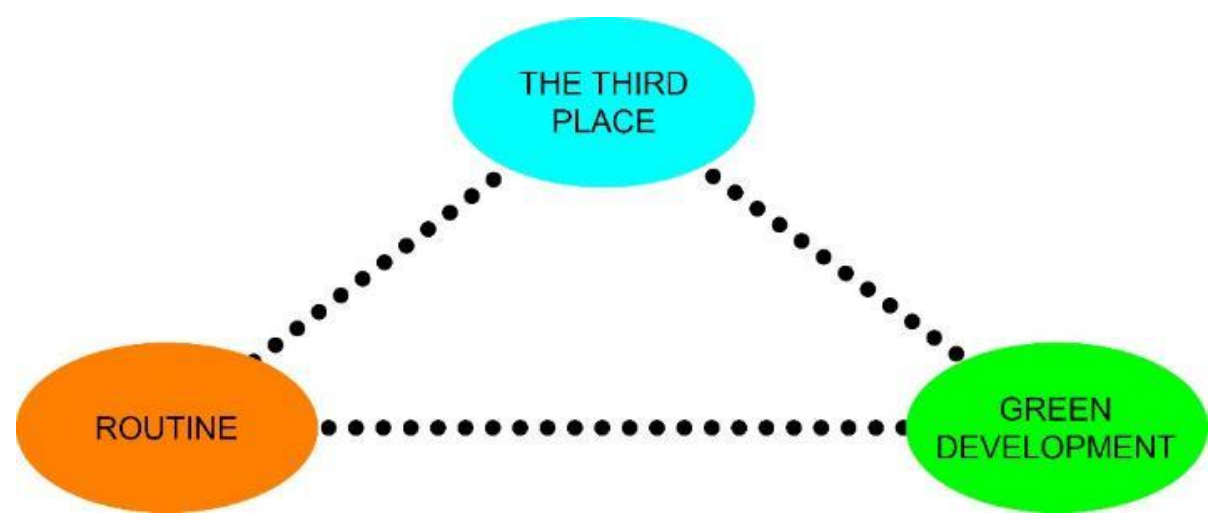

Gambar 10. Diagram elemen solusi

Sumber: Penulis, 2019

The Third Place dengan berbagai elemen yang membentuknya merupakan sebuah panduan untuk membangun suatu ruang publik yang ideal dan efektif. Teori tersebut dipadukan dengan teori Green Development atau pembangunan hijau sebagai konsep pembangunan dalam upaya membantu dalam penyelesaian masalah yang ada serta dipadukan dengan elemen rutinitas sehari-hari, karena penyelesaian masalah ini tidak boleh terlepas dari kehidupan sehari-hari. Dari ketiga elemen tersebut yang dipadukan menghasilkan proyek yang berjudul Rumah Kaca Pinggir kota di Daan Mogot.

Keseluruhan proyek mengutamakan para pendatang yang datang dengan berjalan kaki atau para pedestrian dengan akses kendaraan yang sangat minimal hanya untuk servis dan administrasi. Fungsi utama berupa greenhouse yang ditunjang dengan komersil, dipadukan dengan beberapa aktivitas publik lainnya. Serta ruang terbuka publik berupa plaza yang dilengkapi dengan taman dan amphitheatre yang ditujukan untuk aktivitas publik.

\section{Ide Perancangan}
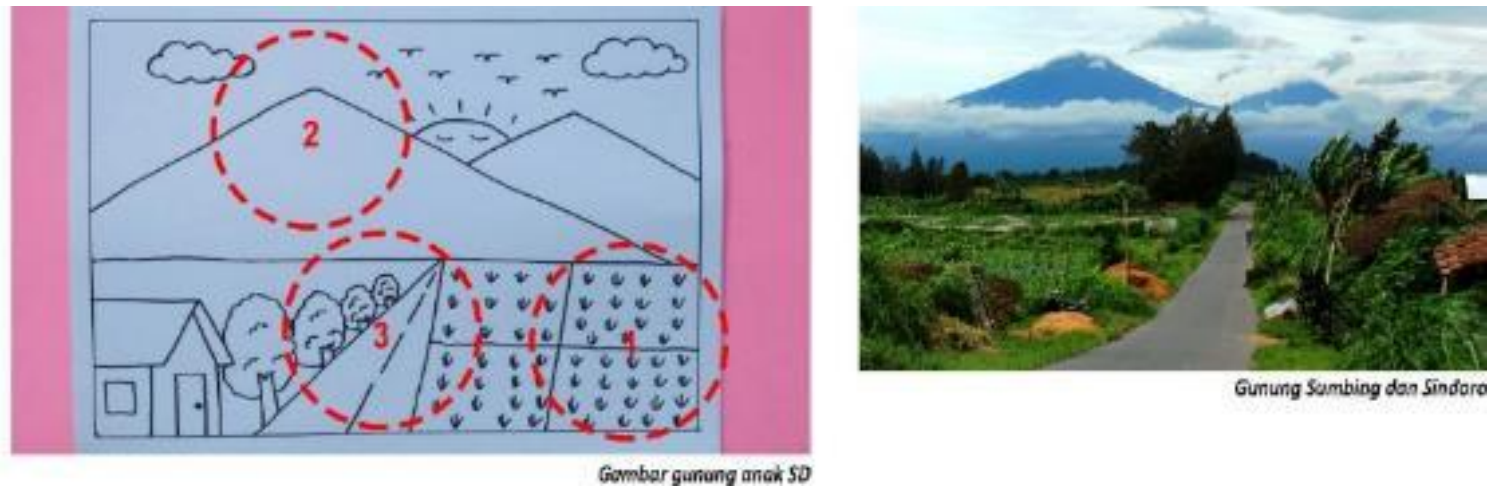

Gambar 11. Ide Massa gambar Anak SD Sumber: Penulis, 2019

Ide perancangan berawal dari sebuah gambar yang dikenal semua orang sejak kecil dan kerap dikaitkan dengan sesuatu yang hijau dan rindang, berupa gambar yang sering diajarkan oleh guru-guru di Sekolah Dasar yaitu berupa dua gunung yang bersebelahan dengan matahari di antaranya dilengkapi dengan rumah dan sawah yang dipisahkan oleh sebuah jalan yang membentang menuju pegunungan tersebut.

Dari ide perancangan tersebut dibagi menjadi empat elemen terpenting dimana tiga diantaranya terkait dengan pembangunan yaitu Gunung, Sawah, dan Jalan: 
a. Sawah menggambarkan sebuah bentuk bangunan berupa terasering menunjukkan suatu desain yang memadukan fungsi ruang dalam dan ruang luar serta menunjukkan bahwa adanya perjalanan di setiap lantainya.
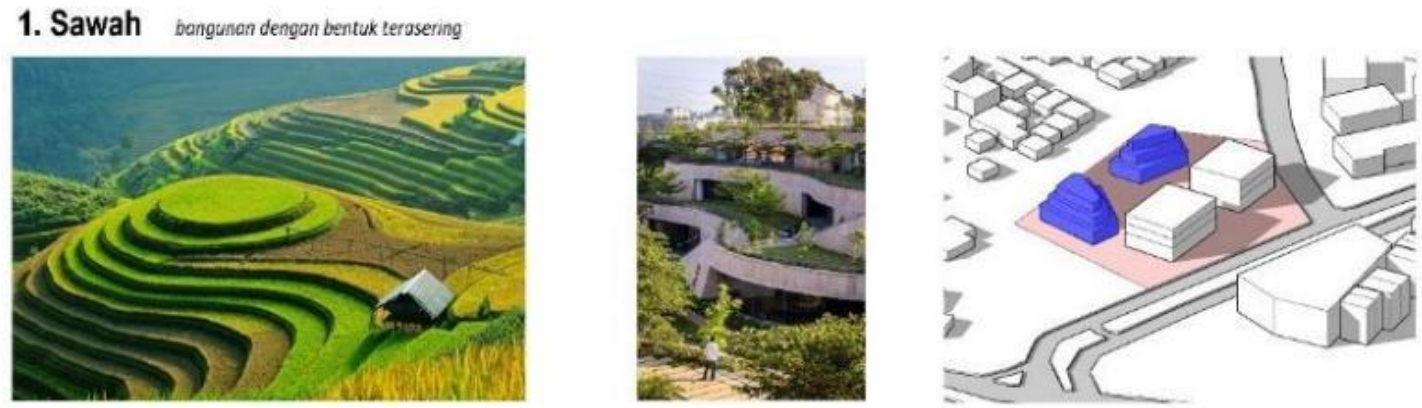

Gambar 12. Sawah dan interpretasinya Sumber: Penulis, 2019

b. Gunung menggambarkan sebuah bentuk yang masif mewakilkan Gedung-gedung pusat perkotaan yang identik dengan kehidupan perkotaan yang stres dan diterjemahkan menjadi fungsi yang lain

2. Gunung bangunan yang mosif namun dapat dijangkau
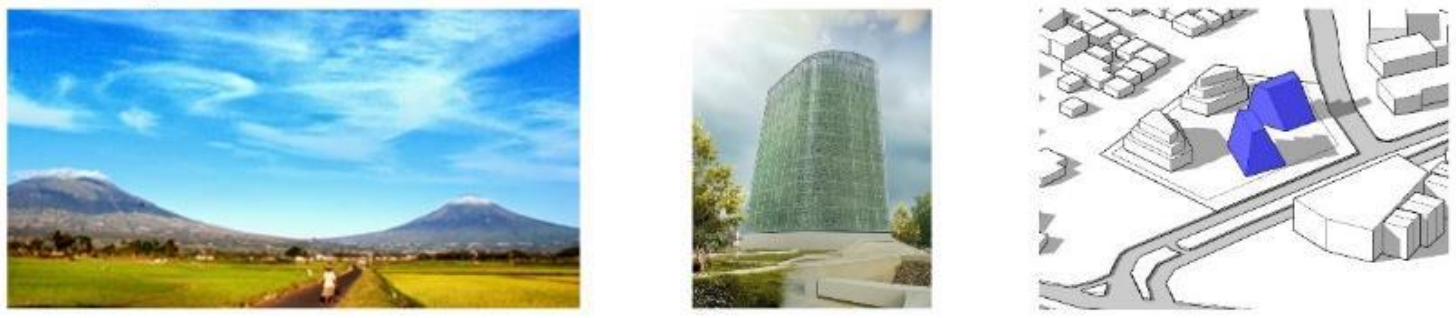

Gambar 13. Gunung dan interpretasinya Sumber: Penulis, 2019

c. Jalan sebagai sarana sirkulasi yang bersifatnya menghubungkan diterjemahkan menjadi sebuah area terbuka yang publik yang bertujuan untuk menghubungkan seluruh fungsi yang ada di tapak dan juga menghubungkan dengan yang ada di luar tapak.

3. Jalan penghubung yang menghubungkan antara bangunan

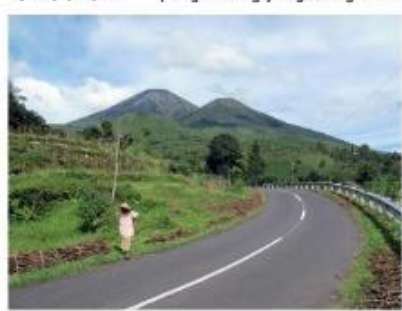

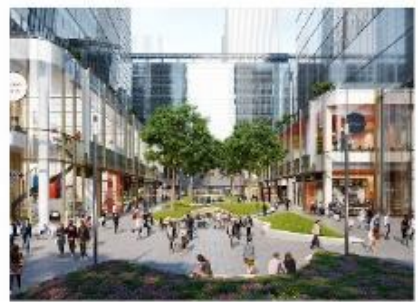

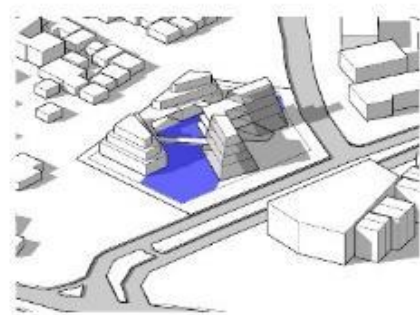

Gambar 14. Jalan dan interpretasinya Sumber: Penulis, 2019 


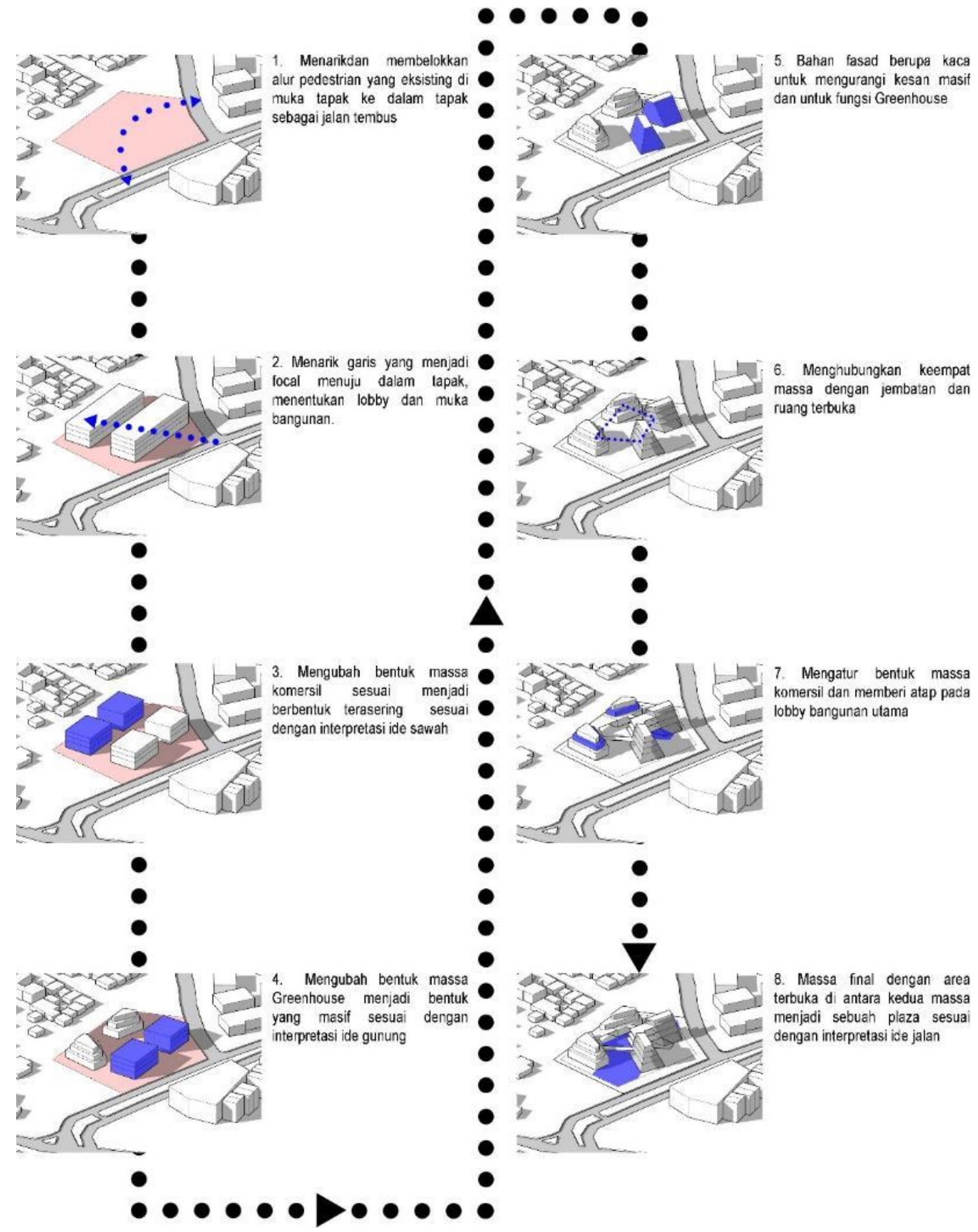

Gambar 15. Proses Gubahan Massa

Sumber: Penulis, 2019 


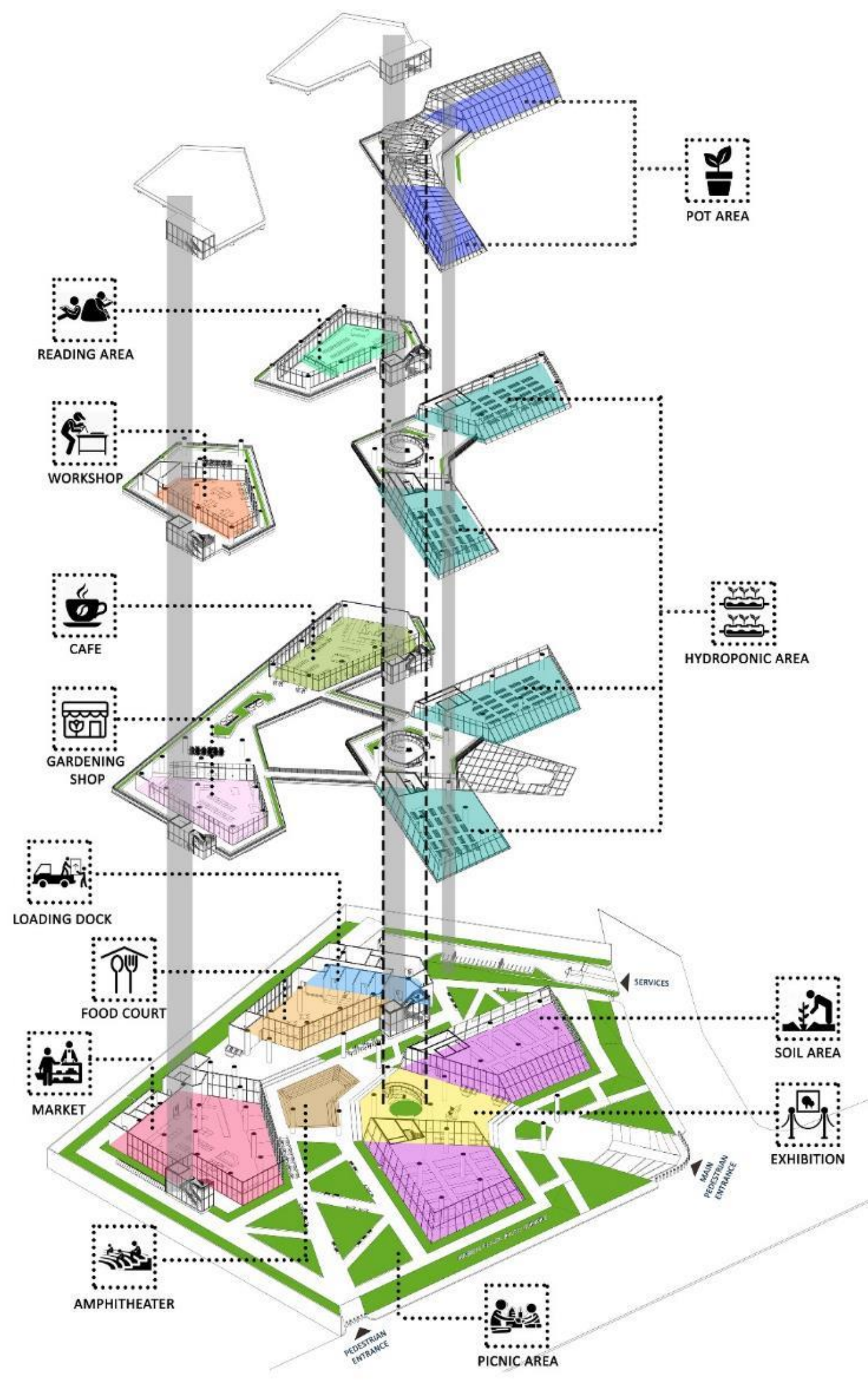

Gambar 16. Program dalam massa

Sumber: Penulis, 2019 


\begin{tabular}{|c|c|c|c|c|c|}
\hline LANTAI & ZONING & FUNGSI & NAMA RUANG & LUAS $\left(M^{2}\right)$ & LUAS TOTAL(M $\left.{ }^{2}\right)$ \\
\hline \multirow{25}{*}{1} & \multirow{2}{*}{ GREENHOUSE } & & LOBBY & 403 & \\
\hline & & & SOIL AREA (AREA BERTANAM TANAH) & 802 & \\
\hline & \multirow{17}{*}{ KOMERSIL } & LOBBY & LOBBY & 188 & \multirow{23}{*}{2596.1} \\
\hline & & \multirow{8}{*}{ FOODCOURT } & LOADING DOCK & 40 & \\
\hline & & & STORAGE & 11 & \\
\hline & & & RUANG KARYAWAN & 5.4 & \\
\hline & & & BACK OF HOUSE & 38 & \\
\hline & & & AREA CUCI & 16 & \\
\hline & & & TENANT AREA & 45 & \\
\hline & & & TENANT AREA (ISLAND) & 20 & \\
\hline & & & AREA MAKAN & 180 & \\
\hline & & \multirow{8}{*}{ MARKET } & LOADING DOCK & 18 & \\
\hline & & & STORAGE & 10 & \\
\hline & & & COLD STORAGE & 6.5 & \\
\hline & & & FREEZER & 4.8 & \\
\hline & & & BACK OF HOUSE & 15 & \\
\hline & & & PREPERATION AREA & 23.4 & \\
\hline & & & MARKET AREA & 280.5 & \\
\hline & & & TENANT AREA (FOOD) & 89 & \\
\hline & \multirow{2}{*}{ PUBLIC } & \multirow{6}{*}{ OUTDOOR } & AMPHITHEATRE & 163 & \\
\hline & & & SITTING AREA & 35 & \\
\hline & \multirow{4}{*}{ SERVICES } & & WC UMUM & 27 & \\
\hline & & & RUANG GENSET \& TRAFO & 25 & \\
\hline & & & CORE & 104 & \\
\hline & & & TANGGA DAN LIFT KOMERSIL & 46.5 & \\
\hline \multirow{13}{*}{2} & \multirow{2}{*}{ GREENHOUSE } & & LOBBY \& COMMUNITY GARDEN & 323 & \multirow{13}{*}{1942.6} \\
\hline & & & HIDROPONIK AREA & 580 & \\
\hline & \multirow{8}{*}{ KOMERSIL } & \multirow{5}{*}{ CAFÉ \& BOOKSTORE } & STORAGE \{BOOKSTORE) & 11.4 & \\
\hline & & & STORAGE [CAFÉ] & 6.8 & \\
\hline & & & BACK OF HOUSE (CAFÉ) & 11 & \\
\hline & & & COUNTER (CAFÉ) & 18.6 & \\
\hline & & & CAFÉ \& BOOKSTORE AREA & 233 & \\
\hline & & \multirow{3}{*}{ GARDENING SHOP } & STORAGE & 16.3 & \\
\hline & & & SHOP AREA & 245 & \\
\hline & & & PLANT SHOP & 75 & \\
\hline & PUBLIC & OUTDOOR & SITTING AREA \& COMMUNITY GARDEN & 300 & \\
\hline & SERVICES & & CORE & 76 & \\
\hline & SETVILES & & TANGGA DAN LIFT KOMERSIL & 46.5 & \\
\hline \multirow{9}{*}{3} & \multirow{2}{*}{ GREENHOUSE } & & LOBBY \& COMMUNITY GARDEN & 249 & \\
\hline & & & HIDROPONIK AREA & 440 & \\
\hline & & READING AREA & ADMIN \&STORAGE & 14 & \\
\hline & KOMERSIL & READIIVO AREEA & READING AREA & 133 & \\
\hline & RUIVIETSIL & WORKSHOP & STORAGE & 15.6 & 1322.1 \\
\hline & & - & WORKSHOP & 185 & \\
\hline & PUBLIC & & SITTING AREA \& COMMUNITY GARDEN & 175 & \\
\hline & SERYICES & & CORE (LIFT, TANGGA KEBAKARAN, WC) & 64 & \\
\hline & SERVICES & & TANGGA DAN LIFT & 46.5 & \\
\hline & GREENHOUSE & & LOBBY \& COMMUNITY GARDEN & 234 & \\
\hline & GREENHOUSE & & POT AREA & 285 & \\
\hline 4 & & & CORE & 24.8 & 615.3 \\
\hline & SERVICES & & TANGGA DAN LIFT KOMERSIL & 46.5 & \\
\hline & & & WATER TANK \& OUTDOOR $A C$ & 25 & \\
\hline & & & & & 6476.1 \\
\hline & SIRKULASI & & $20 \%$ TOTAL LUAS & & 1295.22 \\
\hline & & & & TOTAL LUAS & 7771.32 \\
\hline
\end{tabular}

Gambar 17. Program Ruang

Sumber: Penulis, 2019 


\section{KESIMPULAN DAN SARAN}

Setelah dilakukan proses kajian teoritis, analisis pembahasan, serta pendekatan secara psikologis, proyek ini diharapkan dapat membantu dalam menghadapi permasalahan berupa stres dan mendorong para pengunjung untuk melakukan aktivitas fisik yang terkait dengan alam guna untuk melepas diri dari penatnya rutinitas kehidupan perkotaan serta membuat diri menjadi lebih sehat. Proyek ini tidak hanya merupakan sebuah tempat singgah bagi para pekerja yang berkomuter saja, tetapi proyek ini dapat menjadi bagian dari kehidupan sehari-hari warga sekitarnya dikarenakan oleh fasilitas yang terdapat pada tapak ini dapat mengisi kebutuhan pangan serta sebagai sarana rekreasi yang berinteraksi langsung dengan alam yang dapat membantu dalam menghadapi permasalahan yang diangkat berupa stres.

Saran yang dapat diberikan adalah agar setiap orang terutama pemerintah untuk menjadi lebih waspada terhadap ruang berupa third place serta Ruang Terbuka Hijau mengingat berbagai manfaat yang dapat diberikan oleh masing-masing ruang terhadap kehidupan manusia dalam kesehariannya. Terutama ketika mengingat jumlah Ruang Terbuka Hijau di Jakarta baru mencapai $30 \%$ dari keseluruhan target yang ditentukan.

\section{REFERENSI}

5 Things You Should Know About Stress (n.d.) diunduh 29 Agustus 2019, $<$ https://www.nimh.nih.gov/health/publications/stress/index.shtml\#targetText=Examples\% 20of\%20stress\%20include\%3A, a\%20job\%2C\%20divorce\%2C\%20or\%20illness

Azizah, K.N. (2019) 15,6 Juta Orang Indonesia Alami Depresi, Cuma 8 Persen yang Berobat diunduh 29 Agustus 2019, <https://health.detik.com/berita-detikhealth/d-4596181/156juta-orang-indonesia-alami-depresi-cuma-8-persen-yang-berobat

Direktorat Jenderal Penataan Ruang (2008) mengenai: Peraturan Menteri Pekerjaan Umum Nomor: 05/PRT/M/2008 tentang Pedoman Penyediaan dan Pemanfaatan Ruang Terbuka Hijau di Kawasan Perkotaan

Dzubak, J. (n.d.). Third Place diunduh 29 Agustus 2019, <https://theartofcharm.com/art-ofpersonal-development/what-is-a-third-place-and-why-do-you-need-one/

Ellard, C. (2012) Stress and The City : How urban life affects the brain and what to do about it diunduh 29 Agustus 2019, <https://www.psychologytoday.com/us/blog/mindwandering/201208/stress-and-the-city

Forsyth, A. (2003). Measuring Density: Working Definitions for Residential Density and Building Density

Jakarta Smart City (2017) diunduh 29 Agustus 2019, $<$ https://smartcity.jakarta.go.id/blog/114/iakarta-akan-memenuhi-kebutuhan-ruangterbuka-hijau

Sustainable Development Goals (2015) diunduh 29 Agustus 2019, <https:// www.undp.org/content/undp/en/home/sustainable-development-goals.html

Wolf, K.L. (2016) Outside Our Doors : The benefits of cities where people and nature thrives diunduh 29 Agustus 2019, $<$ https://www.nature.org/content/dam/tnc/nature/en/documents/Outside Our Doors re port.pdf 
